\title{
Early interspecific interference in the wheat/faba bean (Triticum aestivum/ Vicia faba ssp. minor) and rapeseed/squarrosum clover (Brassica napus var. oleifera/Trifolium squarrosum) intercrops
}

\author{
Paolo Benincasa, Roberta Pace, Giacomo Tosti, Francesco Tei \\ Dipartimento di Scienze Agrarie ed Ambientali, Università di Perugia, Italy
}

\begin{abstract}
Most of researches on intercrops evaluate performances and interference between species on the basis of final yield, while little knowledge is available on the interference in early stages and at the root level, at least for cultivated intercrops. In fact, in the few studies on this subject species are often combined minding at experimental needs (e.g. common substrate, temperature and water requirements, easy root separation) more than at their actual use in the farm. The present work evaluates interspecific interference during early developmental stages for two intercrops of agricultural interest: soft wheatfaba bean and rapeseed-squarrosum clover. Improving this knowledge would help intercrop growth modelling and rational cultivation. The experiments were carried out on soft wheat (Triticum aestivum), faba bean (Vicia faba var. minor), rapeseed (Brassica napus var. oleifera) and squarrosum clover (Trifolium squarrosum), germinated and grown until 32 days after sowing (DAS) as one-species stands or as wheat/faba bean and rapeseed/squarrosum clover intercrops, with different densities and proportions for the two species in each couple. Germination was studied in controlled-temperature chamber, plantlet growth was studied on pots in the greenhouse. During germination no interspecific interference was observed for both wheat/faba bean and rapeseed/squarrosum clover intercrops. During plantlet growth, interspecific interference occurred in both intercrops causing variations in whole plant and root dry matter accumulation. In the wheat/faba bean intercrop each species suffered from the competitive effect of the companion species and faba bean was the dominant species when present in lower proportion than wheat. The unexpectedly high aggressivity of faba bean may be explained either with the greater seed size that
\end{abstract}

Correspondence: Dr. Paolo Benincasa, Dipartimento di Scienze Agrarie ed Ambientali, Università di Perugia, Borgo XX Giugno 74, 06121 Perugia, Italy. Tel. +39.075.5856315 - Fax: +39.075.5856344. E-mail: paoloben@unipg.it

Key words: competition, facilitation, germination, initial growth, root.

Received for publication: 28 September 2011.

Accepted for publication: 13 December 2011.

CC Copyright P. Benincasa et al., 2012

Licensee PAGEPress, Italy

Italian Journal of Agronomy 2012; 7:e24

doi:10.4081/ija.2012.e24

This article is distributed under the terms of the Creative Common Attribution Noncommercial License (by-nc 3.0) which permits any noncommercial use, distribution, and reproduction in any medium, provided the original author(s) and source are credited. could have represented an initial advantage within the short duration of the experiment or with the competition towards wheat for substrate nitrogen $(\mathrm{N})$, which is not usual in the open field for a $\mathrm{N}$ fixing species. In the rapeseed/squarrosum clover intercrop, rapeseed was facilitated by squarrosum clover, while squarrosum clover suffered from the competitive effect of rapeseed, which was the dominant species. The resource use efficiency of intercrops as compared to that of one-species crops was lower in the wheat/faba bean couple, not much different in the rapeseed/squarrosum clover one. In both couples, the best performance was observed when the ratio of the dominant species was lower than that of the companion species (number of plants in the ratio 1:3).

\section{Introduction}

There is a renewed interest towards intercrops especially in lowinput cropping systems, but in most cases intercrops are still cultivated empirically. On the contrary, intercrops should be conceived and managed on the basis of scientific knowledge on the interference between intercropped species with the aim to maximize crop growth and yield (Trenbath, 1976; Willey, 1979a,b; Vandermeer, 1989; Malézieux et al., 2009). Many indices have been proposed to express plant competition and intercrop performance (Weigelt and Jolliffe, 2003). In order to obtain an yield gain from the intercrop the interspecific competition has to be lower than the intraspecific competition (de Wit and Van den Bergh, 1965; Snaydon and Satorre, 1989), and at least one species should be facilitated (i.e. should take advantage) from the presence of the companion species (McGilchrist and Trenbath, 1971; Markham and Chanway, 1996; Zhang and Li, 2003; Hauggaard-Nielsen and Jensen, 2005; Tosti et al., 2010).

Positive interspecific interference has been observed in many intercrops often due to the different ability of species in getting hold of nutrients and let part of them available to the companion species (Zhang and Li, 2003; Dakora and Phillips, 2002; Li et al., 2003). This normally happens for the nitrogen $(\mathrm{N})$ derived from atmosphere by legumes and partly released to companion non legumes (Høgh-Jensen, 2006; Xiao et al., 2004). Most studies on intercrops have been carried out in the open field looking at the final yield at harvest as an overall effect of the interference between species integrated over the whole growing cycle. On the contrary, only few studies concerned early interference (Tofinga et al., 1993; Bellostas et al., 2003; Bedoussac and Justes, 2010), especially at the below-ground level where changes in root growth and architecture may occur (Tofinga et al., 1993; Li et al., 2006; Båth et al., 2008; Tosti and Thorup-Kristensen, 2010). This because, besides the well known difficulties in studying roots, it is hard to discriminate roots from different species (Thorup-Kristensen, 2001). Actually the few combinations of species studied till now have been chosen minding at distinguish roots from different species more 
than for their actual use in cultivation (Ilgen and Stamp, 1992; Bellostas et al., 2003; Tosti and Thorup-Kristensen, 2010).

The aim of the present work was to evaluate the interspecific interference during early developmental stages for the two intercrops wheat-faba bean and rapeseed-squarrosum clover, both of agricultural interest. The former is widespread in the world and mediterranean environments as permanent or temporary intercrop for production of fodder and food (Xiao et al., 2004; Tosti et al., 2007; Tosti and Guiducci, 2010), the latter may have perspectives as both forage and green manure crop (Benincasa et al., 2010). The choice of the two intercrops above was motivated by the environmental needs of species to be combined: in fact, the species of each couple must have similar needs for germination and early growth, so that experimental conditions (germination substrate, moisture, temperature, light, etc.) could not favour or hamper one species with respect to the other.

\section{Materials and methods}

The experiments were carried out on soft wheat (Triticum aestivum), faba bean (Vicia faba var. minor), rapeseed (Brassica napus var. oleifera) and squarrosum clover (Trifolium squarrosum), germinated and grown until 32 days after sowing (DAS) as one-species stands or as wheat/faba bean and rapeseed/squarrosum clover intercrops, with different densities and proportions for the two species in each couple.

Germination was studied in controlled-temperature chamber at $20 \pm 1^{\circ} \mathrm{C}$ and in the dark. Wheat (W) and faba bean (F) were incubated in $190 \mathrm{~mm}$-diameter Petri dishes with $650 \mathrm{~g}$ of siliceous sand and 127 $\mathrm{mL}$ water, rapeseed (R) and squarrosum clover (C) in $140 \mathrm{~mm}$-diameter Petri dishes on filter paper (Whatman grade 1) with $7 \mathrm{~mL}$ water. Petri dishes were enveloped in plastic bags to preserve substrate moisture (Bahizire, 2007). Treatments were W12, W24, W48, W96, F6, F12, F24, F48, W6/F6, W12/F12, W24/F24, W48/F24 for the first couple, R25, R50, R100, R200, C25, C50, C100, C200, R25/C25, R50/C50, R100/C100 for the second couple, the numbers indicating the seeds of each species per Petri dish. A completely randomized design with 3 replicates (Petri dishes) was used. Final \% germination (G) was measured as the cumulated number of daily germinated seeds until 14 days after the start of incubation. A seed was considered as germinated when radicle extrusion was higher than $2 \mathrm{~mm}$. Time to reach $50 \%$ of G (T50) was calculated according to Coolbear et al. (1984) as:

$$
\left.\mathrm{T} 50=\mathrm{t}_{\mathrm{i}}+\left(\left((\mathrm{N}+1) / 2-\mathrm{n}_{\mathrm{j}}\right) / \mathrm{n}_{\mathrm{j}}\right) \mathrm{n}_{\mathrm{j}}-\mathrm{n}_{\mathrm{i}}\right) \times\left(\mathrm{t}_{\mathrm{j}}-\mathrm{t}_{\mathrm{i}}\right)
$$

where $\mathrm{N}$ is the final number of germinated seeds and $n_{i}$ and $n_{j}$ represent the total number of germinated seeds at time $t_{i}$ and $t_{j}$, with $\mathrm{n}_{\mathrm{i}}<(\mathrm{N}+1) / 2<\mathrm{n}_{\mathrm{j}}$.

Plantlet growth was studied on pots in the greenhouse. Seeds were sown in $70 \mathrm{~mm}$ diameter pots containing $900 \mathrm{~cm}^{3}$ of siliceous sand. Treatments were W6, W12, F3, F6, F12, W9/F3, W6/F6 for the first couple, R5, R10, R20, C10, C20, R5/C15, R10/C10 for the second couple, the numbers indicating the plantlets of each species actually growing per pot. Therefore, the interference between the two species of each couple could be studied either in the 1:1 ratio, in line with the approach used in previous studies (Bellostas et al., 2003), or in the 1:3 ratio which is closer to that adopted in ordinary cultivation of these intercrops (Benincasa et al., 2010; Tosti and Guiducci, 2010). A randomized block design with 3 replicates (each replicate consisting of 8 pots, i.e. 2 pots by 4 sampling dates) was used. Pots were regularly watered until plant emergence, afterwards a nutrient solution made of Flory $9(1 \mathrm{~g} / \mathrm{L})$, Urea $(0.1 \mathrm{~g} / \mathrm{L})$ and Sequestrene $(0.04 \mathrm{~g} / \mathrm{L})$ was used. The cumulated amounts of $\mathrm{N}, \mathrm{P}_{2} \mathrm{O}_{5}$ and $\mathrm{K}_{2} \mathrm{O}$ supplied per pot were, in order, 99,35 and
$113 \mathrm{mg}$. Plantlet growth was measured by sampling all plantlets from 2 pots at 11, 18, 25, 32 days after sowing. Root and shoot fresh and dry weights (oven dried at $105^{\circ} \mathrm{C}$ for $48 \mathrm{~h}$ ) were measured.

Interspecific interference was expressed in terms of Aggressivity index (AI) (McGilchrist and Trenbath, 1971) and Relative Neighbour Effect (RNE) (Markham and Chanway, 1996). The AI was calculated according to McGilchrist and Trenbath (1971) as:

$$
\mathrm{Al}_{\mathrm{A}}=\left(\mathrm{P}_{\mathrm{AB}} / \mathrm{P}_{\mathrm{AA}}-\mathrm{P}_{\mathrm{B} A} / \mathrm{P}_{\mathrm{BB}}\right) ; \mathrm{AI}_{\mathrm{B}}=\left(\mathrm{P}_{\mathrm{BA}} / \mathrm{P}_{\mathrm{BB}}-\mathrm{P}_{\mathrm{AB}} / \mathrm{P}_{\mathrm{AA}}\right)
$$

where $\mathrm{AI}_{\mathrm{A}}$ and $\mathrm{AI}_{\mathrm{B}}$ are the aggressivity indices for the species $\mathrm{A}$ and $\mathrm{B}$, $P_{A B}$ and $P_{A A}$ the dry weight per plant for the species $A$ in the intercrop $(A+B)$ and the pure stand $(A)$, respectively, both at the same total plant density (i.e. for the wheat/faba bean couple: F12, W12, W6/F6, W9/F3; for the rapeseed/squarrosum clover couple: R20, C20, R10/C10, R5/C15), PBA and PBB are the dry matter yield per plant for the species $B$ in the intercrop $(A+B)$ and the pure stand $(B)$, respectively, both at the same total plant density. If $\mathrm{AI}_{A}=\mathrm{AI}_{B}=0$, the two species have similar competitive abilities. If $\mathrm{AI}_{\mathrm{B}}>0$ (and $\mathrm{AI}_{A}<0$ ), then $\mathrm{B}$ is the dominant species, vice versa if $\mathrm{AI}_{\mathrm{A}}>0$ (and $\mathrm{AI}_{\mathrm{B}}<0$ ).

The RNE was calculated according to Markham and Chanway (1996) as:

$$
\mathrm{RNE}=\left(\mathrm{P}_{\text {pure }}-\mathrm{P}_{\text {inter }}\right) / \mathrm{x}
$$

where $P_{\text {pure }}$ and $P_{\text {inter }}$ are the dry weight per plant of one species in the pure stand and the intercrop, respectively, $x=P_{\text {pure }}$ if $P_{\text {pure }}>P_{\text {inter }}$ and $x=$ $\mathrm{P}_{\text {inter }}$ if $\mathrm{P}_{\text {inter }}>\mathrm{P}_{\text {pure }}$. RNE $<0$ indicates facilitation, RNE $>0$ indicates competition.

The yield gain (or loss) due to the intercrop as compared to the pure stand was expressed as Relative Yield Total (RYT) (de Wit and Van den Bergh, 1965):

$$
\mathrm{RYT}=\mathrm{RY}_{\mathrm{A}}+\mathrm{RY}_{\mathrm{B}}
$$

with

$$
\mathrm{RY}_{\mathrm{A}}=\mathrm{Y}_{\mathrm{AB}} / \mathrm{Y}_{\mathrm{AA}} ; \mathrm{RY}_{\mathrm{B}}=\mathrm{Y}_{\mathrm{BA}} / \mathrm{Y}_{\mathrm{BB}}
$$

where $R Y_{A}$ and $R Y_{B}$ represent the relative yields for species $A$ and species $B, Y_{A B}$ and $Y_{A A}$, are the dry matter yield per unit area for the species $A$ in the intercrop $(A+B)$ and the pure stand $(A)$, respectively, $Y_{B A}$ and $Y_{B B}$ are the dry matter yield per unit area for the species $B$ in the intercrop (A+B) and the pure stand (B), respectively.

$\mathrm{RY}=1, \mathrm{RY}<1$, and $\mathrm{RY}>1$ indicate in order no interference, competition, facilitation towards one species by the companion species (Austin et al., 1988).

RYT $=1$ RYT $>1$, RYT $<1$ indicate in order invariance, increase or decrease of yield in the intercrop as compared to the one-species crop (Snaydon and Satorre, 1989).

Data on germination and plantlet growth from each couple of species were submitted to ANOVA according to a completely randomized design (germination) or to a completely randomized block design (plantlet growth). The G\% data had been previously arcsin square root transformed prior to statistical analysis. Means were compared by least significant difference at $\mathrm{P}=0.05$.

\section{Results}

No significant difference was observed for $\mathrm{G}$ and T50 between treatments from each couple of species, either considering one-species or two-species crop densities (Tables 1 and 2). On the contrary, differences between treatments from each couple were observed for plantlet 
growth (Figures 1 and 2). Some differences were already appreciable at 25 DAS, but most and main differences were generally recorded at 32 DAS. As far as the wheat/faba bean couple is concerned, the plantlet from W12 at 32 DAS had total and root dry weights higher than the wheat plantlet from W6/F6 and W9/F3 in spite of the same total plant density (Figure $1 \mathrm{~A}, \mathrm{C}$ ). At the same time, the plantlet of F12 had total and root dry weights higher than the faba bean plantlet from W9/F3, while the faba bean plantlet in W6/F6 and W9/F3 did not differ (Figure $1 \mathrm{~B}, \mathrm{D})$. The RNE calculated on total and root dry weights was positive for both species (Figure $3 \mathrm{~A}, \mathrm{D})$. The AI of faba bean calculated on total and root dry weight was $>1$ in the W9/F3 and around zero in the W6/F6 throughout the growing period (Figure $3 \mathrm{~B}, \mathrm{E}$ ). The RY values for both

Table 1. Final percentage of germination and time to obtain $50 \%$ of germination for soft wheat and faba bean incubated at different seed densities as one-species stands (wheat at 12, 24, 48, 96 seeds per Petri dish; faba bean at 6, 12, 24, 48 seeds per Petri dish) and two-species stands (wheat/faba bean at 6/6, 12/12, $24 / 24$ and 48/24 seeds per Petri dish). Values are means of 3 replicates. Arcsin square root transformed data for germination are reported in brackets.

\begin{tabular}{|c|c|c|c|c|}
\hline \multirow[t]{3}{*}{ Seed number } & \multicolumn{4}{|c|}{ Species } \\
\hline & \multicolumn{2}{|c|}{ Wheat } & \multicolumn{2}{|c|}{ Faba bean } \\
\hline & $\begin{array}{l}\text { T50 } \\
\text { (d) }\end{array}$ & $\begin{array}{c}\text { G } \\
(\%)\end{array}$ & $\begin{array}{l}\text { T50 } \\
\text { (d) }\end{array}$ & $\begin{array}{c}\text { G } \\
(\%)\end{array}$ \\
\hline 6 & - & - & 3.17 & $100.0(90.0)$ \\
\hline 12 & 3.05 & $93.9(75.7)$ & 3.04 & $100.0(90.0)$ \\
\hline 24 & 3.01 & $100.0(90.0)$ & 3.05 & $100.0(90.0)$ \\
\hline 48 & 2.97 & $99.4(85.6)$ & 3.09 & $99.4(85.6)$ \\
\hline 96 & 3.00 & $94.8(76.8)$ & - & - \\
\hline $6 / 6$ & 3.04 & $98.0(81.9)$ & 2.96 & $100.0(90.0)$ \\
\hline $12 / 12$ & 2.98 & $90.4(72.0)$ & 3.02 & $100.0(90.0)$ \\
\hline $24 / 24$ & 3.01 & $99.5(85.9)$ & 3.02 & 99.5 (85.9) \\
\hline $48 / 24$ & 3.07 & $89.2(70.8)$ & 3.11 & $89.0(70.6)$ \\
\hline
\end{tabular}

T50, time to obtain $50 \%$ of germination; $G$, germination; Least Significant Difference ( $P=0.05$; degrees of freedom =16): Wheat: 0.041 for T50 and 16.12 for arcsin square root transformed values of G; Faba bean: 0.049 for T50 and 5.93 for arcsin square root transformed values of G.

Table 2. Final percentage of germination and time to obtain $50 \%$ of germination (for rapeseed and squarrosum clover incubated at different seed densities as one-species stands (rapeseed or squarrosum clover at $25,50,100,200$ seeds per Petri dish) and twospecies stands (rapeseed/squarrosum clover at 25/25, 50/50, $100 / 100$ seeds per Petri dish). Values are means of 3 replicates. Arcsin square root transformed data for germination are reported in brackets.

\begin{tabular}{lcccc} 
Seed number & \multicolumn{2}{c}{ Wheat } & \multicolumn{2}{c}{ Faba bean } \\
& $\begin{array}{c}\text { T50 } \\
\text { (d) }\end{array}$ & $\begin{array}{c}\text { G } \\
\text { (\%) }\end{array}$ & $\begin{array}{c}\text { T50 } \\
(\text { d })\end{array}$ & $\begin{array}{c}\text { G } \\
(\%)\end{array}$ \\
\hline 25 & 3.08 & $89.9(71.5)$ & 3.04 & $91.1(72.6)$ \\
50 & 3.04 & $89.7(71.3)$ & 3.09 & $84.1(66.5)$ \\
\hline 100 & 3.10 & $92.9(74.5)$ & 3.05 & $86.2(68.2)$ \\
200 & 3.04 & $92.0(73.6)$ & 3.01 & $94.2(76.1)$ \\
\hline $25 / 25$ & 3.07 & $86.9(68.8)$ & 3.02 & $89.9(71.5)$ \\
$50 / 50$ & 3.09 & $90.5(72.0)$ & 3.04 & $88.8(70.4)$ \\
\hline $100 / 100$ & 3.11 & $94.1(75.9)$ & 3.04 & $94.4(76.3)$ \\
\hline
\end{tabular}

T50, time to obtain $50 \%$ of germination; G, germination; Least Significant Difference ( $\mathrm{P}=0.05$; degrees of freedom =16): Wheat: 0.041 for T50 and 16.12 for arcsin square root transformed values of G; Faba bean: 0.049 for T50 and 5.93 for arcsin square root transformed values of $\mathrm{G}$. species was always lower than the proportion of the species in the couple, thus the RYT was lower than 1 in both W9/F3 and W6/F6 (Figure 3 C,F). As compared to W9/F3, W6/F6 had double RY for faba bean but half RY for wheat, in spite of $1 / 3$ decrease of wheat plant number.

As far as the rapeseed/squarrosum clover couple is concerned, the rapeseed plantlet from $\mathrm{R} 20$ had total and root dry weights not different from that in R10/C10, but lower than that from R5/C15 (Figure $2 \mathrm{~A}, \mathrm{C}$ ), in spite of the same total plant density. Moreover the rapeseed plantlet in $\mathrm{R} 5$ grew as much as in R5/C15. On the other hand the squarrosum clover plantlet from $\mathrm{C} 20$ had a root dry weight higher than that from $\mathrm{R} 5 / \mathrm{C} 15$ and much higher than that from R10/C10, while no difference was observed between squarrosum clover root dry weights in $\mathrm{C10}$ and C20 (Figure 2 B,D). Differences between treatments on squarrosum clover whole plantlet were risible.

The RNE calculated on total and root dry weights was always positive for squarrosum clover and negative for rapeseed in both R5/C15 and R10/C10 (Figure 4 A,D). In particular, rapeseed RNE was lower in $\mathrm{R} 5 / \mathrm{C} 15$ and squarrosum clover RNE was higher in R10/C10. For squarrosum clover in $\mathrm{R} 10 / \mathrm{C} 10$ the RNE calculated on whole plant dry weight was lower than that on root dry weight. The AI of rapeseed calculated on both total and root dry weight was generally $>1$ and higher in R5/C15 than R10/C10 (Figure $4 \mathrm{~B}, \mathrm{E}$ ). The RY on the whole plant dry weight of rapeseed was 0.50 in R5/C15 and increased of $28 \%$ in R10/C10, but it was halved for squarrosum clover (from 0.59 in $\mathrm{R} 5 / \mathrm{C} 15$ to 0.29 in R10/C10) (Figure 4 C,F). Therefore, the RYT was higher than 1 for $\mathrm{R} 5 / \mathrm{C} 15$, lower for R10/C10.
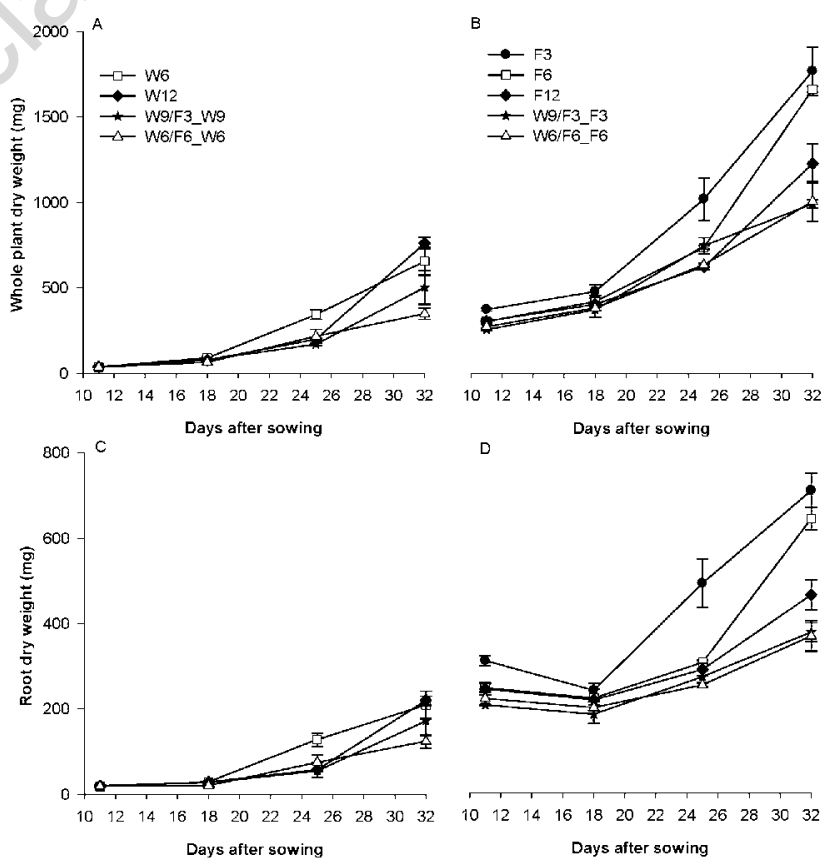

Figure 1. Time course of dry weight accumulation per individual in wheat $A$ ) whole plant and C) roots and in faba bean B) whole plant and $\mathrm{D}$ ) roots as affected by plant density in pure stands (W6, W12: wheat at 6 and 12 plantlets per pot, respectively; F3, F6, F12: faba bean at 3,6,12 plantlets per pot, respectively) and by plant number ratio in intercrops (W9/F3_W9, W6/F6_W6: wheat in W9/F3 and W6/F6, respectively; W9/F3_F3, W6/F6_F6: faba bean in W9/F3 and W6/F6, respectively). Symbols are means of 3 replicates. Vertical bars represent standard errors of the means (SEMs). The standard errors of the differences (SEDs) at 32 days after sowing are, in order, 99.5, 152.7, 35.4, 49.1 for A, B, C, D. 


\section{Discussion}

Results on germination indicate that during this stage there was no interference between species, at least in terms of $\mathrm{G}$ and T50, even at the highest seed densities which were so far higher than those used for actual crops. Consider that 200 seeds in a $140 \mathrm{~mm}$ diameter Petri dish $\left(153.86 \mathrm{~cm}^{2}\right)$ would correspond to over 10,000 seeds per $\mathrm{m}^{2}$, which is not a likely density indeed in the actual crop cultivation. Results are in agreement with those obtained by Bellostas et al. (2003), who did not observe differences between treatments during germination for both the couples rapeseed/pea, and barley/pea. The lack of interference at this stage was expected, considering the limited fluxes of substances allowed by seed coats and the very short time of coexistence for the two species, however it could not be given for granted especially in presence of rapeseed, whose seeds contain glucosinolates which may have phyto-toxic effects (Hansson et al., 2011).

Results on plantlet growth and derived competition indices indicate the occurrence of early interference in both couples of species. As expected, the interference increased as plants grew, thus the discussion will mainly concern differences between treatments recorded at 32 DAS. In the wheat/faba bean couple, each species suffered from the competition by the companion species more than from intraspecific competition (RNE $>0$ ). The competition of wheat caused a reduced growth of faba bean whole plant and root in both W9/F3 and W6/F6, thus independent of wheat plant number. Similar early competitive effect by the cereal was observed by Bellostas et al. (2003) in the couple barley/pea and is in agreement with evidences from open field experiments (Danso et al., 1987; Brandsæter and Netland, 1999; Ghaley et al., 2005) where cereals come out as good competitors when intercropped with legumes, thanks to higher root density and growth rates (Ofori and Stern, 1987). On the other hand, also faba bean caused a competi-

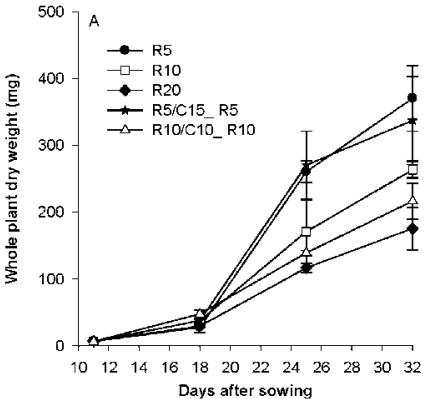

B
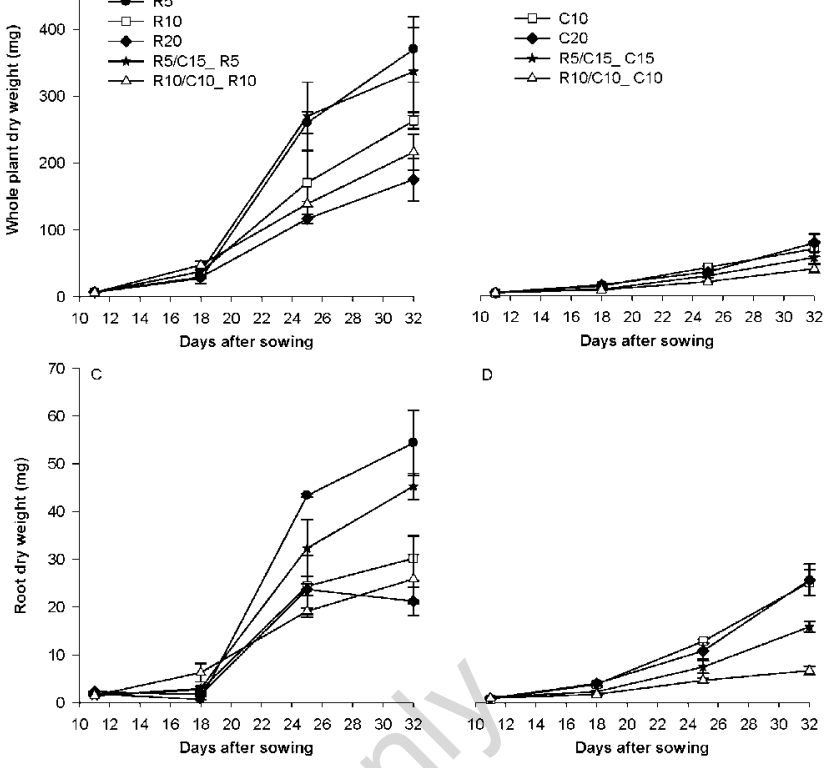

Days after sowing

Figure 2. Time course of dry weight accumulation per individual in rapeseed A) whole plant and C) roots and in squarrosum clover B) whole plant and D) roots as affected by plantlet density in pure stands (R5, R10, R20: rapeseed at 5, 10, 20 plantlets per pot, respectively; C10, C20: squarrosum clover at 10 and 20 plantlets per pot, respectively) and by plant ratio in intercrops (W9/F3_F3, W6/F6_F6: faba bean in W9/F3 and W6/F6, respectively; W9/F3_W9, W6/F6_W6: wheat in W9/F3 and W6/F6, respectively). Symbols are means of 3 replicates. Vertical bars represent standard errors of the means (SEM). The standard errors of the differences (SEDs) at 32 days after sowing are, in order, 56.4, 14.0, 6.6, 2.8 for A, B, C, D.
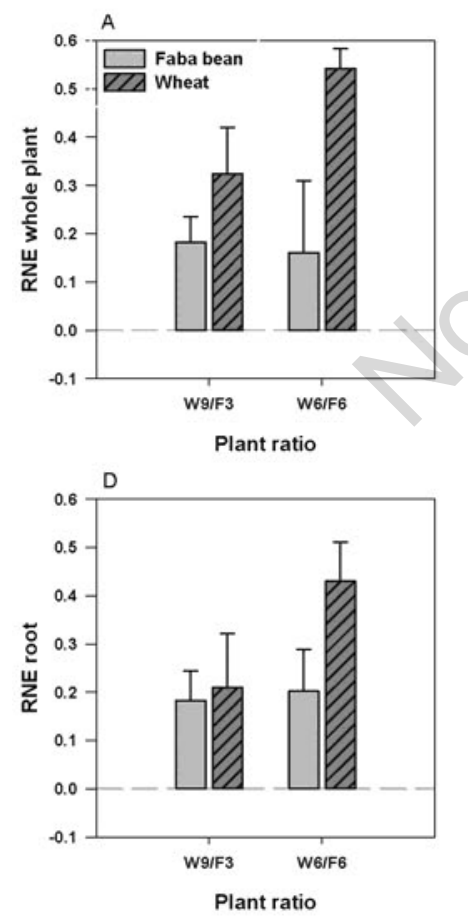
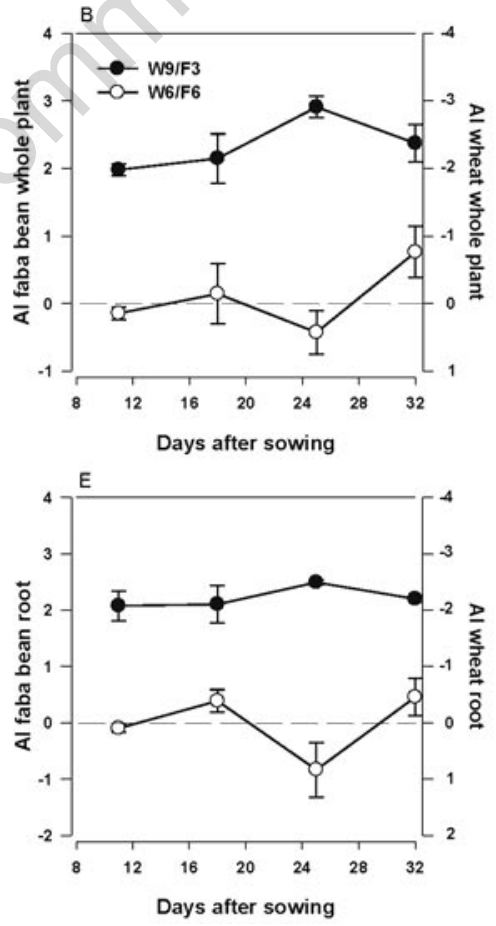
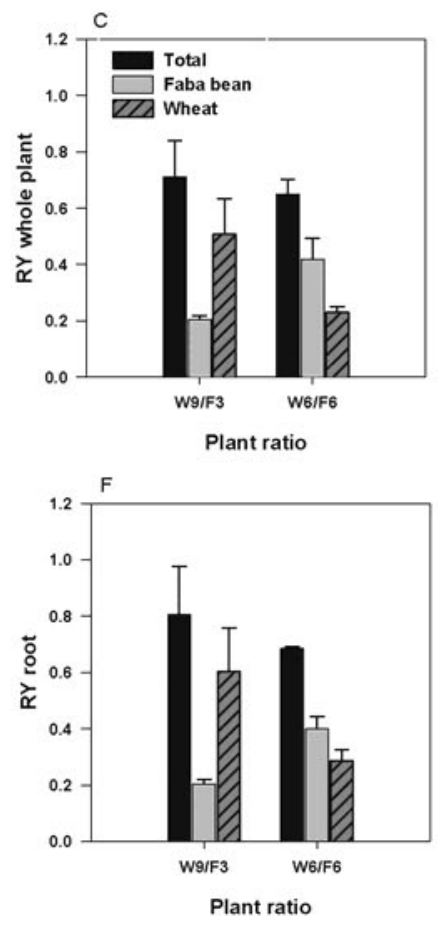

Figure 3. Relative neighbour effect (RNE) at 32 days after sowing, time course of aggressivity index (AI), and relative yield (RY) at 32 days after sowing calculated on dry weights of $A, B, C$ ) the whole plant and D, E, F) roots for the wheat/faba bean (W/F) intercrop at $9 / 3$ and 6/6 plantlets per pot. Values are means of 3 replicates. Vertical bars represent standard errors of the means. The relative yield total (RYT) is the sum of the partial RY calculated for the two species. 

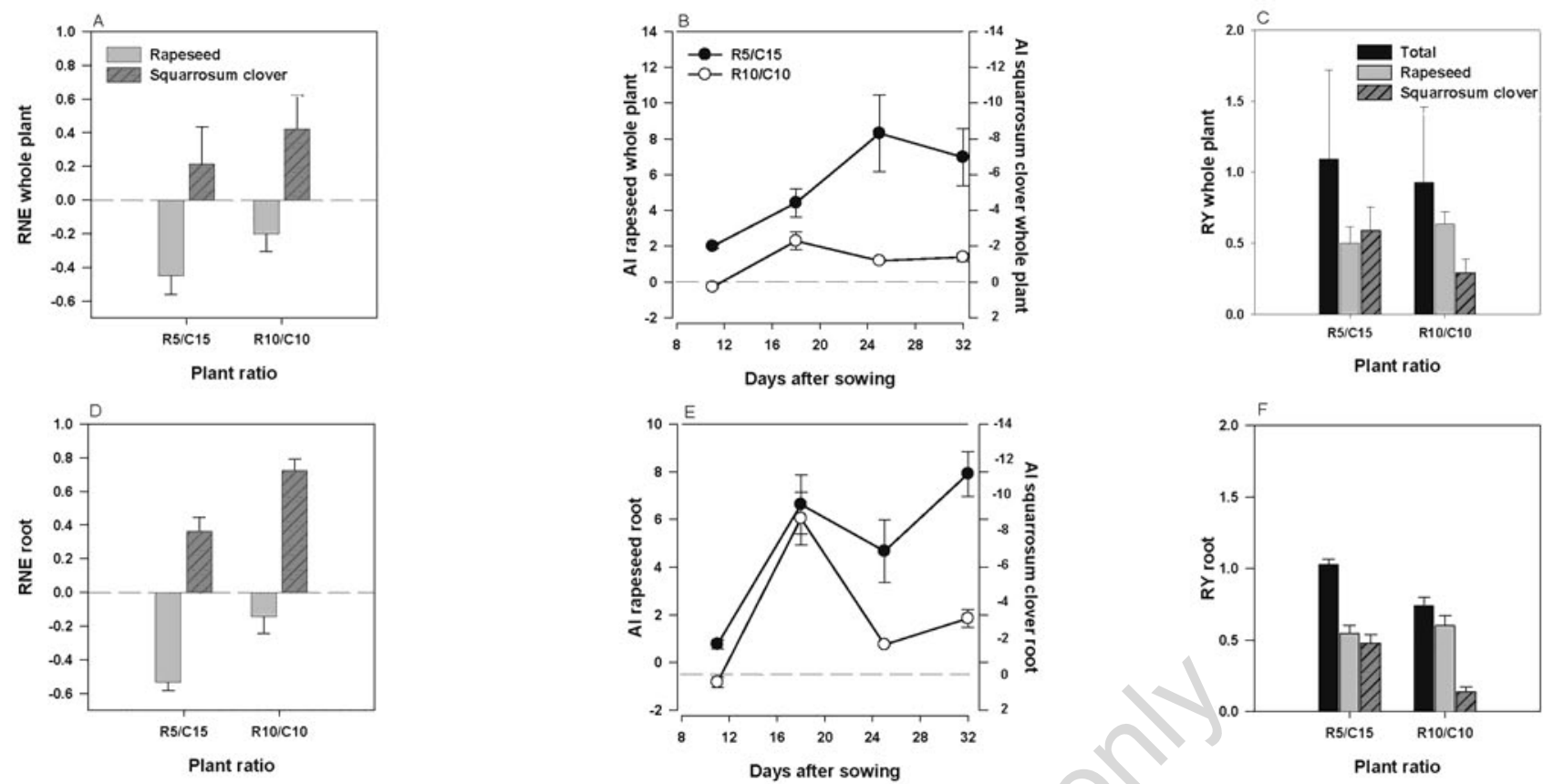

Figure 4. Relative neighbour effect (RNE) at 32 days after sowing, time course of aggressivity index (AI), and relative yield (RY) at 32 days after sowing calculated on dry weights of $A, B, C$ ) the whole plant and D, E, F) roots for the rapeseed/squarrosum clover (R/C) intercrop at $15 / 5$ and $10 / 10$ plantlets per pot. Values are means of 3 replicates. Vertical bars represent standard errors of the means. The relative yield total (RYT) is the sum of the partial RY calculated for the two species.

tive effect towards wheat. In W9/F3 faba bean was the dominant species (AI>1), while in W6/F6 the two species had same aggressivity. The competitive effect of faba bean towards wheat was not expected and is probably due to the greater seed size of faba bean, which could have involved an initial advantage (Marañon and Grubb, 1993; Swanboroug and Westoby, 1996). The advantage related to the greater seed size not necessarily stands in later stages (Fenner, 1983; Shipley and Peters, 1990; Chacón and Muñoz, 2007) but could have made the difference within the very short duration of our experiment. Moreover, in our experiment faba bean competed for mineral $\mathrm{N}$ in the soil, while this generally does not happen in the open field thanks to symbiothic $\mathrm{N}$ fixation (Jensen, 1996; Hauggaard-Nielsen et al., 2001). As a consequence of competitive effects observed in both species, intercrops were less efficient than pure crops in using resources for growth $(\mathrm{RYT}<1)$. This is in contrast with evidences from open field studies (HauggaardNielsen et al., 2009), and is mainly to be ascribed to the competitive effect of faba bean discussed above.

In the rapeseed/squarrosum clover intercrop, rapeseed suffered from intraspecific competition more than from competition by squarrosum clover. Indeed, the presence of squarrosum clover did not affect rapeseed biomass yield (e.g. compare R5/C15 and R5). After all, rapeseed was facilitated by squarrosum clover $(\mathrm{RNE}<0)$ in the sense that it could take advantage from the higher availability of space and resources that squarrosum clover was not able to use (McConnaughay and Bazzaz, 1991). In agreement with evidences by Ilgen and Stamp (1992), rapeseed had a slow growth until 18 DAS, similar to the squarrosum lover one, afterwards the increase of rapeseed growth rates is to be ascribed to its ability in producing a lot of thin and short roots. On the other hand squarrosum clover suffered from rapeseed competition which increased with rapeseed proportion. An inhibitory effect due to allelopathic substances released from hydrolysis of glucosinolates could be also hypothesized, as it has been observed for weeds (Tawaha and Turk,
2003) and cultivated plants (Jurges, 1978; Ju et al., 1983) in the presence of Cruciferae species. For squarrosum clover, the main effect of interspecific competition was the decrease of root growth, especially at higher rapeseed ratio (R10/C10).

Rapeseed was the dominant species and the best performance of the intercrop (RYT>1) was achieved when it was present in lower proportion. It is worth to notice that $\mathrm{R} 5 / \mathrm{C} 15$ is also the ratio closer to that likely to use in actual crop cultivation (Benincasa et al., 2010). The study of this couple for longer than 32 DAS would increase the present limited knowledge on intercrops between oilseed and legume species (Waterer et al., 1994).

\section{Conclusions}

Our results indicate that no interspecific interference occurred during germination of wheat/faba bean and rapeseed/squarrosum clover intercrops. In both intercrops, interference between species was observed during plantlet growth starting from three weeks after emergence and caused variations in the whole plant and root dry matter accumulation. In the wheat/faba bean intercrop each species suffered from the competitive effect of the companion species and faba bean was the dominant species when present in lower proportion than wheat. In the rapeseed/squarrosum clover intercrop, rapeseed was facilitated by squarrosum clover, while squarrosum clover suffered from the competitive effect of rapeseed, which was the dominant species. The resource use efficiency of intercrops as compared to that of one-species crops was lower in the wheat/faba bean couple, not much different in the rapeseed/squarrosum clover one. In both couples, the best performance was observed when the ratio of the dominant species was lower than that of the companion species (number of 
plants in the ratio 1:3). Our results may represent useful information to model initial growth of intercrops and stimulate further studies on the physiological mechanisms that regulate interference between intercropped species, focusing on root growth and architecture.

\section{References}

Austin MP, Fresco LFM, Nicholls A0, Groves RH, Kaye, PE, 1988. Competition and relative yield: estimation and interpretation at different densities and under various nutrient concentrations using Silybum marianum and Cirsium vulgare. J. Ecol. 76:157-171.

Bahizire FB, 2007. Effect of salinity on germination and seedling growth of canola (Brassica napus L.). Degree Diss., University of Stellenbosh, South Africa.

Båth B, Kristensen HL, Thorup-Kristensen K, 2008. Root pruning reduces root competition and increases crop growth in a living mulch cropping system. J. Plant Interact. 3:211-221.

Bedoussac L, Justes E, 2010. Dynamic analysis of competition and complementarity for light and $\mathrm{N}$ use to understand the yield and the protein content of a durum wheat-winter pea intercrop. Plant Soil 330:37-54.

Bellostas N, Hauggaard-Nielsen H, Andersen MK, Jensen ES, 2003. Early interference dynamics in intercrops of pea, barley and oilseed rape. Biol. Agric. Hortic. 21:337-348.

Benincasa P, Tosti G, Tei F, Guiducci M, 2010. Actual N availability from winter catch crops used for green manuring in maize cultivation. J. Sustain. Agr. 34:705-723.

Brandsæter L0, Netland J, 1999. Winter annual legumes for use as cover crops in row crops in northern regions: I. Field experiments. Crop Sci. 39:1369-1379.

Chacón P, Muñoz AA, 2007. Competitive abilities among seedlings of three tree species differing in seed size: a garden experiment using species of Chilean temperate forest. New Zeal. J. Bot. 45: 593-603.

Coolbear P, Francis A, Grierson D, 1984. The effect of low temperature pre-sowing treatment on the germination performance 46 and membrane integrity of artificially aged tomato seeds. J. Exp. Bot. 35:1609-1617.

Dakora FD, Phillips DA, 2002. Root exudates as mediators of mineral acquisition in low-nutrient environments. Plant Soil 245:35-47.

Danso S, Zapata F, Hardarson G, Fried M, 1987. Nitrogen fixation in fababeans as affected by plant population density in sole or intercropped systems with barley. Soil Biol. Biochem. 19:411-415.

de Wit CT, Van den Bergh JP, 1965. Competition between herbage plants. Neth. J. Agr. Sci. 13:212-221.

Fenner M, 1983. Relationships between seed weight, ash content and seedling growth in twenty-four species of Compositae. New Phytol. 95:9-19.

Ghaley B, Hauggaard-Nielsen H, Hogh-Jensen H, Jensen ES, 2005. Intercropping of wheat and pea as influenced by nitrogen fertilization. Nutr. Cycl. Agroecosys. 73:201-212.

Hansson D, Morra MJ, Borek V, Snyder AJ, Johnson-Maynard JL, Thill DC, 2011. Ionic Thiocyanate (SCN-) Production, Fate, and Phytotoxicity in Soil Amended with Brassicaceae Seed Meals. J. Agric. Food Chem. 56:3912-3917.

Hauggaard-Nielsen H, Ambus P, Jensen ES, 2001. Temporal and spatial distribution of roots and competition for nitrogen in pea-barley intercrops - a field study employing P-32 technique. Plant Soil 236:63-74

Hauggaard-Nielsen H, Gooding M, Ambus P, Corre-Hellou G, Crozat Y, Dahlmann C, Dibet A, von Fragstein P, Pristeri A, Monti M, 2009. Pea-barley intercropping for efficient symbiotic N2-fixation, soil N acquisition and use of other nutrients in European organic cropping systems. Field Crops Res. 113:64-71.

Hauggaard-Nielsen H, Jensen ES, 2005. Facilitative root interactions in intercrops. Plant Soil 274: 237-250.

Høgh-Jensen H, 2006. The nitrogen transfer between plants: an important but difficult flux to quantify. Plant Soil 282:1-5.

Ilgen B, Stamp P, 1992. Root Development in Seedlings of Oilradish, White Mustard and Pea. J. Agron. Crop Sci. 169:122-127.

Ju HY, Bible BB, Chong C, 1983. Influence of ionic thiocyanate on growth of cabbage, bean and tobacco. J Chem. Ecol. 9:1255-1262.

Jurges K, 1978. Glucosinolates in the growing and flowering plants of Brassica napus and Brassica campestris. pp 57-60 in Proc. 5th Int. Rapeseed Conf., Malmo, Sweden.

Li L, Sun J, Zhang F, Guo T, Bao X, Smith FA, Smith SE, 2006. Root distribution and interactions between intercropped species. Oecologia 147:280-290.

Li L, Tang C, Rengel Z, Zhang F, 2003. Chickpea facilitates phosphorus uptake by intercropped wheat from an organic phosphorus source. Plant Soil 248:297-303.

Malézieux E, Crozat Y, Dupraz C, Laurans M, Makowski D, OzierLafontaine H, Rapidel B, de Tourdonnet S, Valantin-Morison M, 2009. Mixing plant species in cropping systems: concepts, tools and models. A review. Agron. Sustain. Dev. 29:43-62.

Marañon T, Grubb PJ, 1993. Physiological basis and ecological significance of the seed size and relative growth rate relationship in Mediterranean annuals. Funct. Ecol. 7:591-599.

Markham J, Chanway C, 1996. Measuring plant neighbour effects. Funct. Ecol. 10:548-549.

McConnaughay KDM, Bazzaz FA, 1991. Is physical space a soil resource? Ecology 72:94-103.

McGilchrist CA, Trenbath BR, 1971. A revised analysis of plant competition experiments. Biometrics 27:659-671.

Ofori F, Stern WR, 1987. Cereal-legume intercropping systems. Adv. Agron. 41:41-90.

Shipley B, Peters RH, 1990. The allometry of seed weight and seedling relative growth rate. Funct. Ecol. 4:523-529.

Snaydon RW, Satorre EH, 1989. Bivariate diagrams for plant competition data: modifications and interpretation. J. Appl. Ecol. 26:10431057.

Swanboroug P, Westoby M, 1996. Seedling relative growth rate and its components in relation to seed size: phylogenetically independent contrasts. Funct. Ecol. 10:176-184.

Tawaha AM, Turk MA, 2003. Allelopathic effects of black mustard (Brassica nigra) on germination and growth of wild barley (Hordeum spontaneum). J. Arid Environ. 33:255-260.

Thorup-Kristensen K, 2001. Are differences in root growth of nitrogen catch crops important for their ability to reduce soil nitrate-N content, and how can this be measured? Plant Soil 230:185-195.

Tofinga MP, Paolini R, Snaydon RW, 1993. A study of root and shoot interactions between cereals and peas in mixtures. J. Agr. Sci. 120:13-24.

Tosti G, Benincasa P, Guiducci M, 2010. Competition and facilitation in hairy vetch-barley intercrops. Ital. J. Agron. 5:239-247.

Tosti G, Guiducci M, 2010. Durum wheat-faba bean temporary intercropping: Effects on nitrogen supply and wheat quality. Europ. J. Agron. 33:157-165.

Tosti G, Guiducci M, Boldrini A, Quaranta F, Melloni S, De Vita P, Li Destri Nicosia 0, 2007. Durum wheat - legume temporary intercrop, effects on weed control, nitrogen supply and wheat quality. pp 83-85 in Proc. Int. Conf. on Organic Agriculture and Food Security, FAO, Roma, Italy.

Tosti G, Thorup-Kristensen K, 2010. Using coloured roots to study root interaction and competition in intercropped legumes and nonlegumes. J. Plant Ecol. 3:191-199. 
Trenbath BR, 1976. Plant interactions in mixed crop communities. In R.I. Papendick, P.A. Sanchez and G.B. Triplett (eds.) Multiple Cropping. ASA Special Publication No. 27, ASA, SSSA, CSSA, Madison, WI, USA, pp 129-169.

Waterer JG, Vessey JK, Stobbe EH, Soper RJ, 1994. Yield and symbiotic nitrogen-fixation in a pea mustard intercrop as influenced by $\mathrm{N}$ fertilizer addition. Soil Biol. Biochem. 26:447-453.
Weigelt A, Jolliffe P, 2003. Indices of plant competition. J. Ecol. 91:707-720. Xiao Y, Li L, Zhang F, 2004. Effect of root contact on interspecific competition and $\mathrm{N}$ transfer between wheat and faba bean using direct and indirect 15N techniques. Plant Soil 262:45-54.

Zhang F, Li L, 2003. Using competitive and facilitative interactions in intercropping systems enhances crop productivity and nutrientuse efficiency. Plant Soil 248:305-312. 